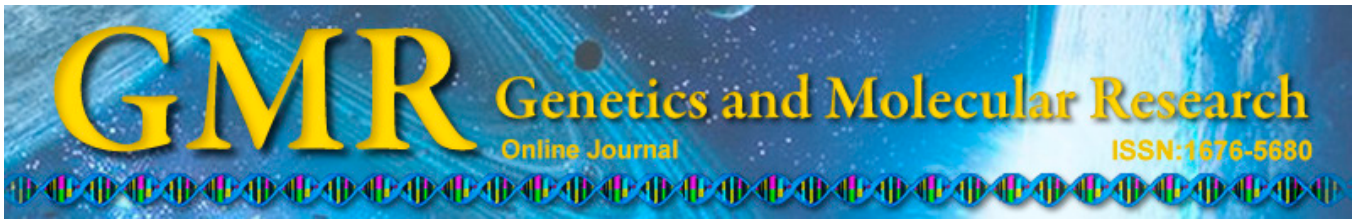

\title{
Adaptability and stability of conilon coffee in areas of high altitude
}

\author{
D.H.G.S. Barbosa ${ }^{1}$, W.P. Rodrigues ${ }^{2}$, H.D. Vieira ${ }^{2}$, F.L. Partelli ${ }^{3}$ and \\ A.P. Viana ${ }^{2}$ \\ ${ }^{1}$ Embrapa Mandioca e Fruticultura, \\ Núcleo de Recursos Genéticos e Desenvolvimento de Variedades, \\ Cruz das Almas, BA, Brasil \\ ${ }^{2}$ Centro de Ciências e Tecnologias Agropecuárias, \\ Universidade Estadual do Norte Fluminense Darcy Ribeiro, \\ Campos dos Goytacazes, RJ, Brasil \\ ${ }^{3}$ Centro Universitário Norte do Espírito Santo, \\ Universidade Federal do Espírito Santo, São Mateus, ES, Brasil \\ Corresponding author: W.P. Rodrigues \\ E-mail: wevertonuenf@hotmail.com
}

Genet. Mol. Res. 13 (3): 7879-7888 (2014)

Received July 22, 2014

Accepted August 21, 2014

Published September 26, 2014

DOI http://dx.doi.org/10.4238/2014.September.26.26

\begin{abstract}
In view of the predicted models of global climate change and differences in prices and production costs, there is increased interest in Coffea canephora cultivation in areas of high altitude. However, this species is sensitive to low temperatures, where genotypes vary regarding adaptation/tolerance mechanisms, demonstrating genotype $\mathrm{x}$ environment interaction. The aim of this study was to evaluate the stability and adaptability of $C$. canephora varieties in high-altitude areas. The experiments were carried out in February 2004, in Bom Jesus do Itabapoana, Rio de Janeiro State, Brazil, at an altitude of $725 \mathrm{~m}$. Four clonal varieties (EMCAPA 8111, EMCAPA 8121, EMCAPA 8131, and EMCAPA 8151) and five harvests (2006 to 2010) were used. The experimental design was randomized blocks with four treatments and six plots, with 12 plants in each plot and spaced $2.5 \times 1.2 \mathrm{~m}$. Adaptability and stability parameters were determined using methods based on
\end{abstract}


nonparametric analysis and analysis of variance. The results showed that the EMCAPA 8131 had the best performance according to stability and adaptability parameters and may be promising for high-altitude regions.

Key words: Coffea canephora; Low temperatures;

Agronomic performance

\section{INTRODUCTION}

In recent years, global consumption of Coffea canephora has been increasing at the rate of $3.25 \%$ per year versus $2.58 \%$ for $C$. arabica, and moreover, price indicators of $C$. $c a$ nephora have increased, while being reduced for C. arabica (IOC, 2014). Still, according to the latest report of the Intergovernmental Panel on Climate Change (IPCC) of 2014, global temperature is predicted to increase by $3.7^{\circ}$ to $4.8^{\circ} \mathrm{C}$ by 2100 , and in this scenario, C. canepho$r a$ cultivation may increase. Assad et al. (2004) analyzed the impact of climate change on $C$. arabica in the São Paulo, Minas Gerais, Paraná, and Goiás states and observed that an increase of $1^{\circ}$ to $3^{\circ} \mathrm{C}$ already causes reductions in the suitable area for cultivation in these regions, if genetic characteristics are maintained. In this context, C. canephora cultivation in these areas could be presented as an option for the farmer.

Generally, C. canephora shows satisfactory growth rates when grown in areas where the minimum temperature is above $17^{\circ} \mathrm{C}$ and the maximum is less than $34^{\circ} \mathrm{C}$ (Partelli et al., 2013). When grown in areas with low temperatures, it shows a drop in net photosynthetic rate and lower photosystem II efficiency (Partelli et al, 2009). However, when exposed to low temperatures gradually, C. canephora has defense/acclimation mechanisms that may enable adjustments to these conditions with different capabilities among cultivars (Ramalho et al., 2014).

Coffee regions have different climatic conditions, and the responses of cultivars differ in different environments due to genotype $\mathrm{x}$ environment interaction (Cucolotto et al., 2007). Methods classifying genotypes according to their stability and adaptability are more suitable to study this interaction in a greater number of environments (Regitano Neto et al., 2013), and thus increase the reliability of the recommendations.

Models that evaluate adaptability and stability have been applied to coffee (Corrêa et al., 2006; Botelho et al., 2010; Nascimento et al., 2010; Rodrigues et al., 2013). However, they have not been applied to C. canephora in areas of high altitude for the selection of genotypes with favorable agronomic characteristics (mostly grain yield) for these conditions.

Adaptability shows the ability of genotypes to respond to environment stimulus, and stability refers to the ability of genotypes to show highly predictable performance against environmental changes (Regazzi and Cruz, 1997).

Various methods are available for the analysis of adaptability and stability. The method proposed by Eberhart and Russell (1966) uses simple linear regression, where the dependent variable (usually grain yield) is expressed in terms of an environmental index that measures the quality of environments assessed, or based on nonparametric statistics (Lin and Binns, 1988). Other methods as proposed by Plaisted and Peterson (1959) and Annicchiarico (1992) based on analysis of variance to estimate the adaptability and stability parameters may have low accuracy (Cruz, 2013), but may be easy to interpret and can be applied with a smaller number of environments (Cargnelutti Filho et al., 2007). 
Thus, the aim of this study was to estimate the stability and adaptability parameters for grain yield of $C$. canephora in areas of high altitude by different statistical methods.

\section{MATERIAL AND METHODS}

The experiments were carried out in February 2004, in Bom Jesus do Itabapoana, northwestern Rio de Janeiro State, Brazil, at an altitude of $725 \mathrm{~m}$, on Oxisol soil. The climate is characterized as Aw, according to the Köppen classification, with a hot and rainy season and another dry and cool season, showing typical tropical climate, with an average temperature of $22^{\circ} \mathrm{C}$ and average rainfall of $1601 \mathrm{~mm}$.

The study consisted of four treatments, namely the genotypes of the clonal varieties designated EMCAPA 8111, EMCAPA 8121, EMCAPA 8131, and EMCAPA 8151. EMCAPA 8111 is composed of vegetative propagation clones and early ripening. EMCAPA 8121 is also composed of vegetative propagation clones but mid ripening. EMCAPA 8131 is composed of vegetative propagation clones but late ripening. EMCAPA 8151 (seeds), also known as Robusta Tropical, results from a combination of elite clones.

The experimental design was randomized blocks, with six plots, and 12 plants in each plot and spaced $2.5 \times 1.2 \mathrm{~m}$. Before planting, the analysis and correction of soil $\mathrm{pH}$ and fertilizing was performed. The seedlings of four varieties were six months old when planted, having been grown from seeds and cuttings of orthotropic shoots.

The harvest of 2006, 2007, 2008, 2009, and 2010 were performed between May and July, according to the maturity time of each variety. The volume of coffee cherries harvested was transformed to bags/ha using the scale of $320 \mathrm{~L}$ coffee cherries per $60 \mathrm{~kg}$ sack, accounting for grain yield.

Methods based on nonparametric analysis (Lins and Binns, 1988; Kuang, 1988) and analyses of variance (Plaisted and Peterson, 1959; Eberhart and Russell, 1966; Annicchiarico, $1992)$ to obtain stability and adaptability parameters were used. The environment was represented by the grain yield in different harvests.

The Lin and Binns (1988) method estimates the stability and adaptability of behavior in a single parameter, $\mathrm{Pi}$, which is estimated by Equation 1:

$$
\mathrm{Pi}=\frac{\sum_{j=1}^{\mathrm{n}}\left(X_{i j}-M_{j}\right)^{2}}{2 n}
$$

where $X_{i j}$ is the grain yield of the cultivar $i$ in environment $j, M j$ is the maximal response observed among all cultivars in environment $j$, and $n$ is the number of environment. Thus, varieties with lower Pi value have more adaptability and stability.

The method proposed by Plaisted and Peterson (1959) quantifies the relative contribution of each genotype for genotype $\mathrm{x}$ environment interaction and identifies those with best stability, obtained by Equation 2:

$$
\theta_{i}=\frac{1}{g-1}\left[\sum_{i^{\prime}}\left(\hat{\sigma}_{g a_{i i^{\prime}}}^{2}\right)\right]\left(\mathrm{i} \neq \mathrm{i}^{\prime}\right) .
$$

(Equation 2)

As $d^{2}{ }_{i i}$ is the squared Euclidean distance between genotypes $i$ and $i$, and based on the behavior of these in environment $a$; therefore: 


$$
d_{i i^{r}}^{2}=\sum_{j}\left(Y_{i j}-Y_{i^{\prime} j}\right)^{2}(\mathrm{j}=1,2, \ldots, \mathrm{a}) .
$$

(Equation 3)

Thus, it is estimated that:

$$
\operatorname{SQ}\left(G_{i i} \times A\right)=\frac{r}{2}\left[d_{i i^{\prime}}^{2}-\frac{1}{a}-\left(Y_{i j}-Y_{i^{\prime} j}\right)^{2} \quad \text { (Equation } 4\right)
$$

and

$$
\hat{\sigma}_{g a_{i i^{\prime}}}^{2}=\frac{\left[\frac{S Q\left(G_{i i^{\prime}} \times A\right)}{(a-1)}\right]-Q M R}{r}
$$

Accordingly, the relative contribution of each cultivar for interaction is estimated by expression 6:

$$
\theta_{i}(\%)=\frac{100 \theta_{i}}{g \widehat{\sigma}_{g a}^{2}{ }_{i i}}
$$

Using the method of Kuang (1988), we proceeded with the ranking of varieties in ascending order based on the estimators $i$ obtained according to Plaisted and Peterson (1959). The following varieties were classified in descending order based on average grain yield. The values of each classification were then summed, obtaining the sum of the ranking, where the summed lower values were described as the most stable and productive varieties. model:

The Eberhart and Russell (1966) method is based on the following linear regression

$$
\mathrm{Y}_{\mathrm{ij}}=\beta_{\mathrm{oi}}+\beta 1_{\mathrm{ilj}}+\delta_{\mathrm{ij}}+\varepsilon_{\mathrm{ij}}
$$

where $Y_{i j}$ is the average grain yield of cultivar $i$ in environment $j, \beta_{o i}$ equals the overall average grain yield of cultivar $i, \beta 1_{i}$ corresponds to the linear regression coefficient, whose estimate is the cultivar response $i$ to environment variation $j$, and $I j$ is the environmental index encoded. The deviations from the regression are represented by $\delta_{i j}$, and $\varepsilon_{i j}$ is the average experimental error. Varieties with $\beta 1_{i}=1$ have general adaptability, and $\beta 1_{i}>1$ and $\beta 1_{i}<1$ show specific adaptability to favorable and unfavorable environments, respectively. The stable varieties exhibit no significant regression deviations, since this estimate is related to the prediction of variety in relation to the linear regression model. Equation 8:

The stability parameter according to the Annicchiarico (1992) method is given by

$$
\omega_{i}=\mu_{i}-I_{(1-\alpha)} \cdot S_{i}
$$

(Equation 8)

where $\omega_{i}$ is the confidence index $(\%), \mu_{i}$ is the average percentage of variety $i, I$ is the percentile $(1-\alpha)$ of the cumulative normal distribution function, and $S_{i}$ is the standard deviation of the percentage values. Varieties with higher $\omega_{i}$ have less chance of being indicated. The simi- 
larity between varieties in relation to methods was calculated by the coincidence index (CI), where $\mathrm{CI}=\mathrm{I} / \mathrm{N}$, with $I$ beginning with the number of times that the variety appears in the same position in the ranking for the different methods and $N$ being the total number of methods. The adaptability and stability parameters were obtained by the Genes software (Cruz, 2013).

\section{RESULTS AND DISCUSSION}

The residual mean squares (Table 1) obtained from the analyses of individual variance (by environment) for grain yield ( $\mathrm{kg} / \mathrm{ha}$ ) showed a ratio of the highest to the lowest values of 11.375 , allowing the inclusion of all environments in the analysis of variance (Regazzi and Cruz, 1997).

$\begin{aligned} & \text { Table 1. Individual analyses of variance of grain yield (in bags of } 60 \mathrm{~kg} / \mathrm{ha} \text { ) for the five harvests (environments) } \\
& \text { of four Coffea canephora varieties in areas of high altitude in the Rio de Janeiro State, Brazil. }\end{aligned}$
\begin{tabular}{lcccr}
\hline Environment & MS Block & MS Variety & MS Residue & F \\
\hline 1 & 19.24871 & 376.12619 & 18.44731 & 20.3892 \\
2 & 31.49134 & 524.93788 & 11.741 & 44.7098 \\
3 & 120.55859 & 1526.53034 & 111.96625 & 13.6338 \\
4 & 14.61104 & 175.85444 & 29.46776 & 5.9677 \\
5 & 119.6139 & 2385.80288 & 133.55675 & 17.8636 \\
d.f. & 5 & 3 & 15 & \\
\hline
\end{tabular}

According to the combined analysis of variance (Table 2), the varieties, environments (grain yield) and varieties $\mathrm{x}$ environment interactions showed a significant effect, justifying the use of methods that rank the varieties according to adaptability and stability. The high significance of the environments was probably related to coffee biannuality, which is attributed to the depletion of reserves of the plants in years with high grain yields, decreasing the following production due to a decreased growth of primary branches (DaMatta et al., 2007).

Table 2. Summary of joint analysis of variance for grain yield (bags of $60 \mathrm{~kg} / \mathrm{ha}$ ) in five harvests (environments) for four Coffea canephora varieties in areas of high altitude in the Rio de Janeiro State, Brazil.

\begin{tabular}{lcc}
\hline SV & d.f. & MS \\
\hline Blocks & 5 & 147.8021 \\
Variety & 3 & $3389.0098^{*}$ \\
Environment & 4 & $20610.7599^{* *}$ \\
Var x Env & 12 & $400.0605^{* *}$ \\
Residue & 95 & 56.4873 \\
Total & 119 & \\
Average & 36.34 & 20.68 \\
CV $(\%)$ & 20.68 & \\
\hline
\end{tabular}

* and **Significant at 1 and $5 \%$ probability, respectively.

Average grain yield and stability parameter (general Pi) based on nonparametric analysis according to Lin and Binns (1988), as well as the decomposition of parameters, are presented in Table 3. Generally, the smaller the Pi value, the lower the deviation will be in relation to the maximum grain yield for each environment. Thus, stability is necessarily related to higher grain yield (Daher et al., 2003). Thus, it is possible to observe that the best variety was EMCAPA 8131, followed by EMCAPA 8121, EMCAPA 8151, and EMCAPA 8111. 
Pi decomposition in favorable and unfavorable environment improves this method (Carneiro, 1998). The decomposition of the stability parameter proposed by Lin and Binns (1988) in part due to favorable environments (those with higher average than the overall average) and unfavorable environments (whose averages are below the overall average), allows the understanding of the response of genotypes to changes in ambient conditions. In the favorable environment, the ranking of the best were EMCAPA 8131, 8151, 8121, and 8111, and in the unfavorable environment, they were EMCAPA 8131, 8121, 8151, and 8111 (Table 3). Considering the Pi estimates together, it can be observed that EMCAPA 8131 stood out, which also had a better average grain yield as the method provided.

Table 3. Estimates of stability and adaptability parameters obtained by Lin and Binns (1988) methodology and grain yield (bags of $60 \mathrm{~kg} / \mathrm{ha}$ ) of four Coffea canephora varieties assessed in five harvests in areas of high altitude in the Rio de Janeiro State, Brazil.

\begin{tabular}{lcccc}
\hline Varieties & Average & General Pi & Favorable Pi & Unfavorable Pi \\
\hline Emcapa 8111 & $24.19^{\mathrm{c}}$ & 423.18 & 858.87 & 132.71 \\
Emcapa 8121 & $37.30^{\mathrm{b}}$ & 127.79 & 248.62 & 47.24 \\
Emcapa 8131 & $49.92^{\mathrm{a}}$ & 0 & 0 & 0 \\
Emcapa 8151 & $33.94^{\mathrm{b}}$ & 165.92 & 225.96 & 125.89 \\
\hline
\end{tabular}

Means followed by the same letter do not differ by the Tukey test at 5\% probability.

According to the Plaisted and Peterson (1959) method, the more stable varieties were, in ascending order, EMCAPA 8121, 8151, 8131, and 8111 (Table 4). However, it can be observed that the variety that produced the most, i.e., EMCAPA 8131 (Table 3), did not show a suitable stability value. This fact was observed by Vilhegas et al. (2001) working with corn genotypes and Daher et al. (2003) working with Pennisetum purpureum Schum genotypes. According to Cargnelutti Filho et al. (2007), cultivars indicated by the Plaisted and Peterson (1959) method are associated with greater stability apart from average grain yield and adaptability to favorable and unfavorable environments.

Table 4. Estimate of stability parameters proposed by Plaisted and Peterson (1959) methodology for grain yield (bags of $60 \mathrm{~kg} / \mathrm{ha}$ ) for four Coffea canephora varieties assessed in five harvests in areas of high altitude in the Rio de Janeiro State, Brazil.

\begin{tabular}{lcc}
\hline Varieties & $\theta_{i}$ & $\theta_{i}(\%)$ \\
\hline Emcapa 8111 & 93.78 & 35.25 \\
Emcapa 8121 & 45.31 & 17.01 \\
Emcapa 8131 & 74.10 & 27.85 \\
Emcapa 8151 & 52.85 & 19.86 \\
\hline
\end{tabular}

To improve the interpretation of the parameters of the Plaisted and Peterson (1959) method, since it is based on the analysis of variance and thus cannot highlight the most promising varieties, Kuang (1988) developed a method to distinguish stable and productive varieties. The varieties that show the lowest sum of the estimator $\theta_{i}(\%)$ (ascending order) and the average (descending order) were the most indicated, presenting itself as more stable and productive. Thus, the best varieties in order of increasing magnitude were EMCAPA 8121, 8131, 8151, and 8111 (Table 5). 
Table 5. Estimates of the stability parameter obtained by Kuang (1988) methodology, based on the $\theta_{\mathrm{i}}$ scoring of Plaisted and Peterson (1959) methodology and the average grain yield for four Coffea canephora varieties assessed in five harvests in areas of high altitude in the Rio de Janeiro State, Brazil.

\begin{tabular}{lccccc}
\hline Varieties & $\theta_{i}(\%)$ & Ranking $\theta_{i}$ & Average & $\begin{array}{c}\text { Ranking of the } \\
\text { average productivity }\end{array}$ & $\begin{array}{c}\text { Sum of Kuang (1988) } \\
\text { Ranking }\end{array}$ \\
\hline Emcapa 8111 & 35.25 & 4 & 24.19 & 4 & 8 \\
Emcapa 8121 & 17.01 & 1 & 37.30 & 2 & 3 \\
Emcapa 8131 & 27.85 & 3 & 49.92 & 1 & 4 \\
Emcapa 8151 & 19.86 & 2 & 33.94 & 3 & 5 \\
\hline
\end{tabular}

The ranking obtained with the Kuang (1988) method showed similarity with that obtained by the Lin and Binns (1988) method, changing the positions of varieties EMCAPA 8131 and EMCAPA 8121. Vilhegas et al. (2001) observed that the Lin and Binns (1988) and Kuang (1988) methods pointed to the same maize genotype, while Daher et al. (2003) observed that the methods pointed to different genotypes of $P$. purpureum. This may be due to the number of genotypes, since the latter authors worked with a larger number of genotypes.

With the Eberhart and Russell (1966) method, the ideal cultivar was the one with high productivity, high adaptability $\left(\beta 1_{i}=1\right)$ and good stability $\left(\sigma^{2} \mathrm{di}=0\right)$. In this study, cultivars with specific adaptability to favorable $\left(\beta 1_{i}>1\right)$ or unfavorable $\left(\beta 1_{i}<1\right)$ environments were not recommended, since the varieties showed no overall adaptability $\left(\mathrm{Bl}_{\mathrm{i}}\right.$ was highly significant for all varieties). Thus, EMCAPA 8131 and 8151 varieties showed specific adaptation to favorable environments, with EMCAPA 8131 showing the highest value and EMCAPA 8111 and 8121 varieties displaying specific adaptations to unfavorable environments and EMCAPA 8111 showing the lowest value (Table 6). Regarding stability, the varieties did not show good stability with highly significant deviations, which was probably related to coffee biannuality.

Table 6. Estimates of adaptability and stability parameters obtained by Eberhart and Russell (1966) methodology for grain yield (bags of $60 \mathrm{~kg} / \mathrm{ha}$ ), assessed in four Coffea canephora varieties in five harvests in areas of high altitude in the Rio de Janeiro State, Brazil.

\begin{tabular}{lccc}
\hline Variety & $\mathrm{B}_{\mathrm{li}}$ & $\widehat{\boldsymbol{\sigma}}_{\boldsymbol{d i}}^{2}$ & $\boldsymbol{R}_{\boldsymbol{i}}^{2}(\%)$ \\
\hline Emcapa 8111 & $0.74^{* *}$ & $46.084^{* *}$ & 93.20 \\
Emcapa 8121 & $0.95^{* *}$ & $21.8339^{* *}$ & 97.94 \\
Emcapa 8131 & $1.23^{* *}$ & $20.4498^{* *}$ & 98.82 \\
Emcapa 8151 & $1.07^{* *}$ & $33.7045^{* *}$ & 97.48 \\
\hline
\end{tabular}

* and **Significant at 1 and $5 \%$ probability respectively by the $t$-test $(\mathrm{Ho}: \beta 1 \mathrm{i}=1.0)$ and $\mathrm{F}$ test $\left(\mathrm{Ho}: \widehat{\sigma}_{d i}^{2}=0\right)$.

The Annicchiarico (1992) method estimates the confidence index, i.e., the probability of success or failure of a variety, associated with a significance level $(\alpha)$. Thus, the EMCAPA 8131 and 8121 varieties showed the highest potential yield, with a $75 \%$ confidence level, where they were respectively capable of a yield of 41.13 and $1.14 \%$ higher than the environmental average. On the other hand, EMCAPA 8111 and 8151 showed, with a $75 \%$ confidence level, the lowest potential yield, where they were only capable of a yield of 41.85 and $21.95 \%$ lower than the environmental average, respectively, and therefore not recommended for planting according to this method (Table 7). Botelho et al. (2010) observed the highest confidence index in the most productive arabica coffee genotypes in three regions of Minas Gerais State, Brazil. 
Table 7. Estimation of the confidence index parameter obtained by Annicchiarico (1992) methodology, for grain yield (bags of $60 \mathrm{~kg} / \mathrm{ha}$ ) assessed in four Coffea canephora varieties in five harvests in the Rio de Janeiro State, Brazil.

\begin{tabular}{lccr}
\hline Varieties & Average (\%) & Deviation (\%) & Wi \\
\hline Emcapa 8111 & 63.96 & 20.03 & 58.482579 \\
Emcapa 8121 & 103.95 & 10.30 & 101.137621 \\
Emcapa 8131 & 148.08 & 25.42 & 141.129007 \\
Emcapa 8151 & 84.01 & 21.77 & 78.055077 \\
\hline
\end{tabular}

Significance level $=0.25$.

There was consistency between the methods of Lin and Binns (1988), based on nonparametric statistics, and Annicchiarico (1992), based on the analyses of variance, in the classification of the best genotypes (EMCAPA 8131 and 8121 ) for both the adaptability and stability parameters and best average grain yield (Table 8 ). The EMCAPA 8131 variety was selected as the best among all, in three of the five methods studied, showing a CI of $60 \%$, followed by EMCAPA 8121, which showed a CI of $40 \%$ for both the first and second position in the ranking. The EMCAPA 8111 variety showed the worst performance in all methods with a CI of $100 \%$ in the last position in the ranking.

Table 8. Ranking of four Coffea canephora varieties for grain yield (bags of $60 \mathrm{~kg} / \mathrm{ha}$ ) in areas of high altitude in the Rio de Janeiro State, Brazil, by different statistical methods and coincidence index (CI) for the highest frequency (parentheses value) of the position in the ranking.

\begin{tabular}{lccccc}
\hline Varieties & $\begin{array}{c}\text { Lin } \\
\text { Binns (1988) }\end{array}$ & $\begin{array}{c}\text { Plaisted and } \\
\text { Peterson (1959) }\end{array}$ & $\begin{array}{c}\text { Kuang } \\
(1988)\end{array}$ & $\begin{array}{c}\text { Eberhart and } \\
\text { Russel (1966) }\end{array}$ & $\begin{array}{c}\text { Annicchiarico } \\
(1992)\end{array}$ \\
\hline Emcapa 8111 & 4 & 4 & 4 & 4 & 4 \\
Emcapa 8121 & 2 & 1 & 1 & 3 & $100(4)$ \\
Emcapa 8131 & 1 & 3 & 2 & 1 & $40(1,2)$ \\
Emcapa 8151 & 3 & 2 & 3 & 2 & $60(1)$ \\
\hline
\end{tabular}

Under low-temperature conditions, clone 02 (early ripening) of the EMCAPA 8111 variety was less tolerant compared to clone 153 (late ripening) of the EMCAPA 8131 variety in relation to photosynthetic rate, chlorophyll fluorescence and zeaxanthin cycle (Partelli et al., 2009). Clone 02 was more efficient in the lipid classes and fatty acid composition (ScottiCampos et al., 2014). This fact confirms the trend found in this study, where the late ripening clone group was often more productive under low temperature conditions, compared to early ripening clones. It is also noteworthy that $C$. arabica was better than C. canephora in practically all physiological and biochemical characteristics when subjected to low temperatures (Partelli et al., 2009; Scotti-Campos et al., 2014, Ramalho et al., 2014).

According to Cargnelutti Filho et al. (2007), genotypes with high productivity and associated with high instability and adapted to favorable environments are indicated by the Lin and Binns (1988) method modified by Carneiro (1998) and Annicchiarico (1992). Corrêa et al. (2006) also observed that these two methods pointed to the same Icatú genotypes cultivated in two regions in Minas Gerais. The Kuang (1987) method showed a tendency towards this same behavior. On the other hand, Eberhart and Russell (1966) and Plaisted and Peterson (1959) methods showed similarities in classifying the most productive genotypes in less stable varieties (Table 8). 
The Eberhart and Russell (1966) and Lin and Binns (1988) methods were poorly correlated, and the use of these have involved only additional information with different approaches to the stability and adaptability studies (Silva and Duarte, 2006).

The Lins and Binns method has the advantage of classifying more stable and more productive varieties, since this method combines stability with the ability of varieties to show the smallest deviation in relation to maximum, in all study environments (Melo et al., 2007).

It is worth mentioning that the different performance between varieties probably involves genetic factors, which can influence the defense/adaptation mechanisms, since there is divergence between the clones (Fonseca et al., 2006). These factors, interacting with the environment are also related to ripening time.

Regarding ripening time, Partelli et al. (2009) observed in C. canephora clones a higher $\mathrm{CO}_{2}$ assimilation rate and increased respiratory activity and starch accumulation in late ripening (clone 153) compared with early ripening (clone 02), when subjected to low temperatures.

Stored carbohydrates are important sources of energy and metabolic compounds that are used during plant development, especially in times that require rapid vegetative and reproductive growth (Silva et al., 2004a). Thus, C. canephora clones that have higher amounts of stored starches and respiratory enzyme activity may have a better ability to sustain the flowering process, after the harvest period, since it is a process that requires a lot of energy (Chaves Filho and Oliveira, 2008), and probably result in higher grain yield. In the study area of this research, the temperature in the winter period (prior to flowering), is still below that considered optimal for this species (Partelli et al., 2013), which could help to understand the factors that contributed to the better performance of the EMCAPA 8131 variety, late ripening, compared to medium and early ripening clones.

Regarding variety recommendation, the EMCAPA 8131 variety had average productivity close to C. arabica planted more in the region, designated Catuaí Vermelho144 (52 bags/ ha), in research done in the same region of this study, with spacing of $2.5 \times 1.0 \mathrm{~m}$ (Andrade et al., 2014). Moreover, in areas of higher altitudes, it is observed that coffee takes longer to complete its cycle which may contribute to increased quality of the grains (Silva et al., 2004b). Nevertheless, it is noteworthy that other studies related to management with the application of pruning and applying optimal densities, among other characteristics must be performed to reduce the biannual effect and thereby improve stability across harvests and regions to ensure the viability of this promising variety in high-altitude areas.

\section{CONCLUSIONS}

The EMCAPA 8131 variety showed the best stability and adaptability parameters of performance of grain yield over years, thus being promising for cultivation in areas of high altitude.

\section{REFERENCES}

Andrade WEB, Guimarães PTG, Faquin V and Guimarães RJ (2014). Produtividade do cafeeiro arábica em condições de adendamento, no noroeste fluminense. Coffee Sci. 9: 90-101.

Annicchiarico P (1992). Cultivar adaptation and recommendation from alfalfa trials in Northern Italy. J. Genet. Breed. 46: $269-278$.

Assad EA, Pinto HS, Zullo Junior J and Ávila AMH (2004). Impacto das mudanças climáticas no zoneamento agroclimático 
do café no Brasil. Pesq. Agropec. Bras. 39: 1057-1064.

Botelho CE, Rezende JC, Carvalho GR, Carvalho AM, et al. (2010). Adaptabilidade e estabilidade fenotípica de cultivares de café arábica em Minas Gerais. Pesq. Agropec. Bras. 45: 1404-1411.

Cargnelutti Filho A, Perecin D, Malheiros EB and Guadagnin JP (2007). Comparação de métodos de adaptabilidade e estabilidade relacionados à produtividade de grãos de cultivares de milho. Bragantia 66: 571-578.

Carneiro PCS (1998). Novas Metodologias de Análise da Adaptabilidade e Estabilidade de Comportamento. Master's thesis, Universidade Federal de Viçosa, Viçosa.

Chaves Filho JT and Oliveira RF (2008). Variação sazonal do amido armazenado em ramos plagiotrópicos do cafeeiro. Estudos 35: 85-102.

Corrêa LVT, Mendes ANG and Bartholo GF (2006). Comportamento progênies de cafeeiro Icatú. Cienc. Agrotecnol. 30 : 618-622.

Cruz CD (2013). Programa Genes (Versão Windows): Aplicativos Computacionais em Genética e Estatística. Universidade Federal de Viçosa, Viçosa.

Cucolotto M, Pípolo VC, Garbuglio DD, Fonseca Junior NS, et al. (2007). Genotype x environment interaction in soybean: evaluation through three methodologies. Crop Breed. Appl. Biotechnol. 7: 270-277.

Daher RF, Pereira MG, Amaral Júnior AT, Pereira WA, et al. (2003). Estabilidade da produção forrageira em clones de capim-elefante (Pennisetum purpureum Schum.). Cienc. Agrotecnol. 27: 788-797.

DaMatta FM, Ronchi CP, Maestri M and Barros RS (2007). Ecophysiology of coffee growth and production. Braz. J. Plant Physiol. 19: 485-510.

Eberhart SA and Russel WA (1966). Stability parameters for comparing varieties. Crop Sci. 6: 36-40.

Fonseca AFA, Sediyama T, Cruz CD, Sakaiyama NS, et al. (2006). Divergência genética em café conilon. Pesq. Agropec. Bras. 41: 599-605.

ICO - International Coffee Organization (2013). Botanical Aspects. Available at [http://www.ico.org/botanical.asp]. Accessed April 3, 2014.

IPCC (2014). Working Group III. Mitigation of Climate Change. Available at [http://report.mitigation2014.org/drafts/finaldraft-postplenary/ipcc_wg3_ar5_final-draft_postplenary_techinical-sumary.pdf] Accessed September 18, 2014.

Kuang MJA (1988). A rank-sum method for selecting high-yielding, stable corn genotypes. Cereal Res. Communities 16: $113-115$.

Lin CS and Binns MR (1988). A superiority measure of cultivar performance for cultivar x location data. Can. J. Plant Sci. 68: 193-198.

Melo LC, Melo PGS, Faria LC, Diaz JLC, et al. (2007). Interação com ambientes e estabilidade de genótipos de feijoeirocomum na Região Centro-Sul do Brasil. Pesq. Agropec. Bras. 42: 715-723.

Nascimento M, Ferreira A, Ferrão RG, Campana ACM, et al. (2010). Adaptabilidade e estabilidade via regressão não paramétrica em genótipos de café. Pesq. Agropec. Bras. 45: 41-48.

Partelli FL, Vieira HD, Viana AP, Santos PB, et al. (2009). Low temperature impact on photosynthetic parameters of coffee genotypes. Pesq. Agropec. Bras. 44: 1404-1415.

Partelli FL, Marré WB, Falqueto AR, Vieira HD, et al. (2013). Seasonal vegetative growth in genotypes of Coffea canephora, as related to climatic factors. J. Agric. Sci. 5: 108-116.

Plaisted RL and Peterson LC (1959). A technique for evaluating the ability of selections to yield consistently in different locations or seasons. Am. Potato J. 36: 381-385.

Ramalho JC, DaMatta FM, Rodrigues AP, Scotti-Campos P, et al. (2014). Cold impact and acclimation response of Coffea spp. plants. Theor. Exp. Plant Physiol. 26: 5-18.

Regazzi AJ and Cruz CD (1997). Modelos biométricos aplicados ao melhoramento genético. Universidade Federal de Viçosa, Viçosa.

Regitano Neto A, Ramos Junior EU, Gallo PB, Freitas JG, et al. (2013). Comportamento de genótipos de arroz de terras altas no estado de São Paulo. Rev. Cienc. Agron. 44: 512-519.

Rodrigues WP, Vieira HD, Barbosa DH, Souza Filho GR, et al. (2013). Adaptability and genotypic stability of Coffea arabica genotypes based on REML/BLUP analysis in Rio de Janeiro State, Brazil. Genet. Mol. Res. 12: 2391-2399.

Scotti-Campos P, Pais IP, Partelli FL, Batista-Santos P, et al. (2014). Phospholipids profile in chloroplasts of Coffea spp. genotypes differing in cold acclimation ability. J. Plant Physiol. 171: 243-249.

Silva EA, DaMatta FM, Ducatti C, Regazzi AJ, et al. (2004). Seasonal changes in vegetative growth and photosynthesis of Arabica coffee trees. Field Crop. Res. 89: 349-357.

Silva RF, Pereira RGFA, Borém FM and Muniz JA (2004). Qualidade do café-cereja descascado produzido na região sul de Minas Gerais. Cienc. Agrotec. 28: 1367-1375.

Silva WCJ and Duarte JB (2006). Métodos estatísticos para estudo de adaptabilidade e estabilidade fenotípica em soja. Pesq. Agropec. Bras. 41: 23-30.

Vilhegas AG, Vidigal Filho PS, Scapim CA, Gonçalves-Vidigal MC, et al. (2001). Efeito de épocas de semeadura e estabilidade de híbridos de milho em plantios de safrinha no noroeste do Paraná. Bragantia 60: 45-51.

Genetics and Molecular Research 13 (3): 7879-7888 (2014)

CFUNPEC-RP www.funpecrp.com.br 